\title{
NTRK2 Gene Mutation
}

National Cancer Institute

\section{Source}

National Cancer Institute. NTRK2 Gene Mutation. NCI Thesaurus. Code C158054.

A change in the nucleotide sequence of the NTRK2 gene. 